\title{
Ribosomal RNA Gene
}

National Cancer Institute

\section{Source}

National Cancer Institute. Ribosomal RNA Gene. NCI Thesaurus. Code C95943.

The genomic sequence that encodes a ribosomal RNA molecule. 